\title{
Effects of COVID-19 pandemic on pediatric endocrinology practice; childhood obesity, pubertal progression and diabetes
}

\author{
COVID-19 pandemisinin çocukluk çağı obezitesi, pubertal progresyon ve tip-1 diyabet \\ üzerine etkisi
}

Elif Sağsak, Zehra Aycan

\begin{abstract}
In the COVID-19 pandemic, millions of people have had to stay in isolation for months. Children did not go to school for a long time, they spent much more time at home and were sedentary. They also spent much more time on screen-related activities (personal computer (PC), mobile phone, music player, tablet, game console, and television (TV). These situations have had various effects on children and adolescents. Undoubtedly, long-term restrictions and lifestyle changes have had effects on individuals with childhood obesity, pubertal progression, and type 1 diabetes (T1D). In this review, articles investigating the effect of COVID-19 quarantine/pandemic on adolescence, childhood obesity and diabetes were compiled and the effect of the COVID pandemic on these frequently encountered situations in pediatric endocrine practice was tried to be revealed.
\end{abstract}

Key words: Pandemic, obesity, puberty, diabetes.

Sagsak E, Aycan Z. Effects of COVID-19 pandemic on pediatric endocrinology practice; childhood obesity, pubertal progression and diabetes. Pam Med J 2022;15:399-406.

Öz

COVID-19 pandemisi, sağlık hizmetleri üzerinde benzeri görülmemiş bir baskı yarattı ve karantina, milyonlarca insanı aylarca evlerinde izole kalmaya zorladı. Pandemi döneminde çocuklar okula gidemediler, evde çok daha fazla zaman geçirdiler ve hareketsiz kaldılar. Ayrıca ekran ilişkili etkinliklerde (bilgisayar, cep telefonu, müzik çalar, tablet, oyun konsolu ve televizyon) çok daha fazla zaman harcadılar. Kuşkusuz bu durumların çocuklar ve ergenler üzerinde çeşitli etkileri olmuştur. Uzun süreli kısıtlamalar ve büyük yaşam tarzı değişiklikleri, hassas bireyleri ve tip 1 diyabet (T1D) gibi kronik hastalıkları olanları etkileyebilir. Bu derlemede, COVID-19 karantinası/ pandemisinin ergenlik, çocukluk çağı obezitesi ve diyabeti üzerine etkisini araştıran makaleler derlenerek pediyatrik endokrin pratiğinde sık karşılaşılan bu durumlara COVID pandemisinin etkisi ortaya koyulmaya çalışılmıştır.

Anahtar kelimeler: Pandemi, obezite, puberte, diyabet.

Sağsak E, Aycan Z. COVID-19 pandemisinin çocukluk çağı obezitesi, pubertal progresyon ve tip-1 diyabet üzerine etkisi. Pam Tıp Derg 2022;15:399-406.

\section{Introduction}

COVID-19 (The coronovirus disease 2019) pandemic created an unprecedented strain on health care and the lockdown forced millions of people to remain isolated in their homes for months [1]. During the pandemic, children could not attend to school, they spent much more time at home and remained inactive. Moreover, they spent much more time on screen-based activitiy (personal compoter (PC), cell phones, music players, tablets, game consoles and television (TV). Undoubtedly, these conditions have had various effects on children and adolescents. Prolonged restrictions and massive lifestyle changes can affect susceptible individuals and those with chronic diseases, such as people with type 1 diabetes (T1D) [2]. In this review, we aimed to investigate the effects of the COVID-19 lockdown/pandemic on puberty, childhood obesity and diagonosis and follow-up of subjects with diabetes.

\section{COVID-19 pandemic and puberty}

Puberty is characterized by the increased release of gonadotropin releasing hormone

Elif Sagsak, Ass. Prof. Instructor Member. Yeditepe University, Department of Pediatrics, Istanbul, Turkey, e-mail: caliskanozturk@yahoo.com (https://orcid.org/0000-0001-7121-1575) (Correspondent Author)

Zehra Aycan, Prof. Ankara University, Department of Pediatrics, Department of Pediatric Endocrinology, Ankara, Turkey, e-mail: zeyraaycan67@ hotmail.com (https://orcid.org/0000-0003-4584-2976) 
$(\mathrm{GnRH})$ by the hypothalamus and leads to the development of sex characteristics, the growth spurt and the reproductive competence. Puberty is influenced by integrated multiple peripheral and central signals [3]. Definitely, genetic factors play a major role. However, there is a consensus that environmental variables, such as weight, foetal nutrition, childhood dietary habits, physical activity, psychological factors, and exposure to electromagnetic fields (EMF) and/or endocrine disrupting chemicals, also have an impact [4].

It is possible that there are correlations between lockdown/pandemic conditions and the frequency of precocious puberty and the rate of pubertal progression. Comprehensive data about this topic is scarce. Probably, lockdown/ pandemic conditions increased the impact of factors interfering with the timing and tempo of puberty, such as adiposity, electronic devices, psychological triggers $[4,5]$. A study from Italy shows a significantly increased incidence of new diagnoses of central precocious puberty (CPP) and a faster rate of pubertal progression in previously diagnosed patients during and after the lockdown for COVID-19 in comparison with the same period of the 5 previous years [4]. In the same study, it is shown that BMI SDS increased significantly in patients diagnosed during and after the lockdown compared to the same period of the previous 5 years [4]. Another study from Italy also reported a significant increase in cases of precocious puberty in girls from the beginning of COVID-19 pandemic, compared to the same 6 months period of 2019 .

The authors conclude that long stays at home, overeating with hypercaloric foods, overnutrition trigger puberty. Additionally education changes with a significant rise of e-learning, extremely uncommon in primary schools before the pandemic, resulted in a larger use of electronic devices, as tablets or personal computers, among children. All these changes may have changed the onset of puberty [6].

Nutrion plays a role in the timinig of puberty [7]. It is not clear how obesity induces the onset of puberty, but visceral fat accumulation has been noted as a metabolic control factor affecting the central nervous system, which controls the onset and progression of puberty, particularly through early activation of periodic GnRH secretion [8].
Closures of schools reduced physical activity, expanded sedantary activities and cause the increase of childhood obesity. Recent studies revealed that changes in lifestyles associated with COVID-19 lockdown caused the increase of obesity prevalence among children and adolescents [9, 10].

A number of studies have recently investigated the effects of exposure to electromagnetic fields on melatonin [11, 12]. Screens emit low and very low frequency electromagnetic waves (radiofrequencies and light) and exposure to them may be associated with decreased melatonin production and 24hour melatonin in children's urine [12]. Nighttime serum melatonin levels are highest in very young children and drop progressively by $80 \%$ throughout childhood until adolescence and young adulthood. Sexual maturation process was found to be associated with the decrease in melatonin measured at night [13]. There is no clinical studies that experimentally tested the effects of melatonin on pubertal timing in children. Animal studies show that exogenous melatonin can suppress $\mathrm{GnRH}$ secretion and reduction in melatonin may accelerate pubertal development [14]. It is possible that the over use of electronic devices during pandemic period leads to the onset of pubertal development by decreasing melatonin.

In a study, the evaluation of the use of electronic devices before and during the lockdown for COVID-19 was questioned and significant increased was observed. The main study use was for school lessons, but also the use for entertainment was increased [7]. One study from Italy confirms that the observation of increased incidence of CPP after lockdown measures. Additionally, in their population, girls with CPP showed higher rates of sleep disturbances and later bedtime compared to controls [15].

During COVID-19 pandemic increased incidence of stress, anxiety and depression have been reported to varying degrees in adults [16], however so far there is little data how children in all countries responded psychologically to crises. The effects of psychological stress on the development of puberty are not clearly known. Stagi et al. [9] reported the importance of psychological factors in precocious puberty in 
children migrating from developing to developed countries.

In conclusion, studies have shown an increase in the incidence of new CPP diagnoses, as well as a faster rate of pubertal progression in previously diagnosed patients, during and after lockdown for COVID-19, suggesting that environmental factors, such as the BMI and the use of electronic devices. Further studies are needed to confirm our knowledge. Clinicians should be aware of the signs of pubertal developmental disorders and should carefully monitor existing patients with CPP for signs of accelerated pubertal progression.

\section{COVID-19 pandemic and childhood obesity}

Obesity is a global public health challenge whose incidence has increased worldwide over the past five decades, reaching pandemic levels [17]. The pathophysiology of excess weight gain is complex with interactions between genetic factors, environment and behavioral factors [18]. The COVID-19 pandemic contributed to the increase in childhood obesity by affecting environmental and behavioral factors. On the other hand, the pandemic may cancel out the existing efforts to curb the obesity epidemic [10].

'Stay-at-home' has been ordered by many countries around the world, in order to restrict the spread of COVID-19. Some countries went into complete lockdowns with only allowance to go out for essential shopping and for restricted physical activity. This led to a number of families panic shopping and storing long shelf life foods that are typically ultra-processed and caloriedense in order to minimize their trips to the supermarket [19]. A recently published Italian study found that the intakes of potato chips, red meat, and sugary drinks increased significantly during the lockdown [20].

Lockdowns are stressful periods. Among all affected, the youth is particular vulnerable population. Lack of in-person contact with classmates, friends, and teachers, and a possible lack of personal space at home are stressors disrupts in children's life during pandemic lockdown [21]. As a consequence, stress-eating of readily available high calorie dense food and sugary beverages ensues [20]. Such actions enhanced the susceptibility to weight gain especially if the amount of daily physical activity was reduced due the restrictions implemented [22].

School closures currently impact over $91 \%$ of the global student population. Children are literally forced to stay at home and are exposed to a different environment than usual [21]. Pre-COVID-19 studies reported that children had higher tendencies to experience weight gain during the summer holidays due to decreased physical activity [23]. According to a study published in 2016 it has been found that obesity increased during summer breaks, by an average of 0.85 percentage points per month (95\% C.I. 0.58-1.12), but decreased during each school year [24]. This findings would project that childhood obesity may be $4.25(0.85 \times 5)$ percentage points (95\% C.I. 2.90-5.60) higher after five months of COVID-19 school closures than before the closures began [25]. According to Brazendale et al. [26], obesogenic behaviors such as sedentary behavior, increased screen time, a poor diet, and irregular sleep are beneficially regulated when children follow a structured day. It is difficult to establish a clear structure for children during pandemic period at home. Closures of schools reduced physical activity opportunities and expanded sedantary activities [19]. Ruopeng An, from USA, designed a study and aimed to build a microsimulation model to project the impact of COVID-19 on childhood obesity in the USA. The model predicts that even a 2-month school closure alone could result in an increase in the childhood obesity rate by 0.640 percentage points among U.S. kindergarteners. If school closures continue to the end of 2020 , the childhood obesity rate in the United States might further increase by $2.373 \%$. If such an impact is universal among all U.S. children aged 5-17 years, by March 2021 approximately 1.27 million new childhood obesity cases will develop [27].

During the first wave of COVID-19, leisure centres including playgrounds were closed off, with an advocacy to stay at home [28]. Children living in urban areas or within small apartments are faced with limited space or opportunities for physical activity and hence they are more susceptible to weight gain [19]. Although higher screen time was beneficial for educational purposes and social communication between children, this can further exacerbate sedantary habits and increase risk for obesity [29]. According to Fang et al. [30], a screen time of $\geq 2$ hours per day significantly increased the 
risk of overweight and obesity among children compared to a screen time of $<2$ hours per day. Pietrobelli et al. [20] reported that screen time increased by approximately five hours per day when compared to the pre-COVID-19 period. Moreover, increased screen media exposure leads to obesity in several ways, including increased eating while viewing [31].

Limited studies have showed the relationship between COVID-19 pandemic and obesity and activity pattern. A recent study in Italy has explored the changes in lifestyles associated with COVID-19 lockdown among 41 children and adolescents with obesity. It revealed that sports activities decreased, sleep time increased, and screen time increased significantly [20]. This reflects life style changes in western countries. On the other hand, from China, Yang et al. [10] reported that, the prevalence of overweight/ obesity has significantly increased in youths, specifically in high school and undergrade students during pandemic. Also they reported that significant changes during COVID-19 lockdown have been observed in patterns of all physical activity, sedentary, sleeping, and screen use variables, with more youths increasing their sedentary, sleeping, and screen time relative to their counterparts who had decreased their physical activity frequency. This study suggested that school administrators should also be informed of these changes, so in-class and/or extracurricular physical activity programs could be designed to counteract them [10].

Consequently, physical activity should be recommended while maintining social distance. We should promote an active lifestyle among children. Families, educational and healthcare systems should engage in supporting system to deal with childhood obesity.

\section{COVID-19 pandemic and type-1 diabetes}

Since the beginning of the pandemic, COVID-19 caused a significant concern for the possible consequences in patients presenting a preexisting chronic condition, such as diabetes [32]. In particular, the majority of the more severe COVID-19 diabetic patients are adults affected by type 2 diabetes. This is due to the pre-existence of micro and macrovascular complications [33]. Several studies conducted for investigate if all patients with diabetes are at risk for COVID-19. These studies show that the prevalence of subjects with T1D affected by COVID-19 is not different from the prevalence of diabetes in the general population [34, 35]. This may be due to the lower prevalence of the COVID-19 among younger people [36]. Moreover, alertness of the T1D patients' to the evolving situation and the careful, precautionary approach they could have taken in protecting themselves before the contagion could strike them [37].

Patients with T1D seem to have a mild form of the disease. The human immunity to foreign antigens, viruses depends on the balance of the Th1 and Th2 immunity. The Th1 immunity is mostly proinflammatory, mediated by $T$ lymphocytes and modulated by IL-6 and Interferon Gamma and its mode of action is against pathogens like Coronavirus. The Th1 immunity is mostly proinflammatory prevalent in the younger age and also T1D versus Th2 immunity. The milder course of the disease in T1D cases could be explained by an imbalance between Th1 and Th2 immunity [38].

The Diabetes Study Group of the Italian Society for Pediatric Endocrinology and Diabetes investigated that in the first two months of pandemic in Italy, the new onsets of T1D are less than those in the same period of 2019. On the other hand, children with DKA presented a more severe form of DKA than in 2019. The lower number of new-onset diabetes cases during the observation period might be due to fear of SARS-CoV-2 exposure and also lower exposure to seasonal viruses [39]. Specific strategies are essential to educate parents about timely attendance at the emergency for children with symptoms that are related to diabetes.

On the other hand, there are some publications abouth diabetic ketoacidosis precipitated by COVID-19 in recent days $[40,41]$. Angiotensin-converting enzyme 2 (ACE2), a key enzyme in the reninangiotensinaldosterone system (RAAS), catalyzes the conversion of angiotensin II to angiotensin ACE2 is highly expressed in the lungs, pancreas and serves as the entry point for SARS-CoV-2. After endocytosis of the virus complex, ACE2 expression is downregulated (40). The binding between the viruses and the receptors provokes a damage of the islets leading to acute diabetes. 
Downregulation of ACE2 after viral entry can lead to unopposed angiotensin II, which may impede insulin secretion. These factors might have contributed to the acute worsening of pancreatic beta cell function and precipitated DKA [40].

It is not clear that alterations of glucose metabolism that occur with a sudden onset in severe COVID-19 persist or remit when the infection resolves. Another unknown point is if COVID-19 change the underlying pathophysiology and the natural history of the patients with preexisting diabetes. Beyond the well-recognized stress response associated with severe illness, more studies are needed to understand potential diabetogenic effect of COVID-19. So far to our knowledge, it is plausible to presume that the pandemic will trigger an increase of T1D cases during the next months/years, especially in people infected by SARS-CoV-2 that are genetically predisposed to diabetes [42].

Moreover, the pandemic was a major challenge in the follow-up of T1D. Pandemic conditions force a distortion in T1D patients daily routine, increasing sedentary behavior, changing eating patterns and exposing to psychological burden. Barchetta et al. [2] from Italy reported that, adults with $\mathrm{T} 1 \mathrm{D}$, blood glucose control significantly worsened as a consequence of the COVID-19 lockdown. They emphasize that socioeconomic issues and psychological burden display detrimental effects on glucose variability even in patients with T1D treated with standard of care therapies and previously in good metabolic control. On the other hand, some published studies show that, despite this unexpected change of lifestyle, patients of all ages with T1D did not experience deterioration in their glucose control during lockdown. Bonora et al. [43] analyzed a group of adult T1D patients using data collected by remote monitoring of glucose sensors and they observed individuals with T1D who stopped working during lockdown significantly improved their glucose control while those who continued working (essential services) showed no change in glucose control. They interpreted this result that slowing down routine daily activities can achieve beneficial effects on the short-term management of T1D. Moreover, Di Dalmazi et al. [44] analyzed patients with T1D (30 children,
24 teenagers,76 adults) using continuous glucose monitoring (CGM). CGM metrics during the 20 days before and the 20 days after lockdown were calculated. CGM parameters during lockdown improved in children, whereas remained unchanged in teenagers. They concluded that, this improvement may reflect the relevant impact of the family environment, in which the mealtime was more regularly distributed during the day and the parents of patients with T1D might have payed closer attention to the management of T1D. Furthermore, they speculated that the influence of the family environment for T1D control may be less relevant in teenagers, differently from children [44]. As a similar study, Aragona et al. [45] evaluated the effect the lockdown imposed during COVID-19 outbreak on the glycemic control of people with T1D using CGM or Flash Glucose Monitoring (FGM). They reported that, in T1D subjects with good glycemic control on CGM or FGM, the lockdown had no negative impact. In addition, they recorded a modest but significant improvement in glycemic control, most likely reflecting more regular daily life activities and reduces work related distress [45]. Consequently, during the lockdown/pandemic condition, the family environment would seem to be more attentive or more dedicated in controlling the disease. Nevertheless, the longterm effects of pandemic and the factors that affect glucose control in this particular situation deserve future investigation.

In this pandemic period, routinely medical activities were reduced. People with a chronic illness would have been deprived by their followup checkups, if it were not for telemedicine. Telemedicine offers a way to be close to patients with T1D, gives a better continuity of the assistance and healthcare and fastens and simplifies the communication between doctors and patients [46].

As a conclusion, It is clear that COVID-19 pandemic has several effects on children and adolescents. The future will reveal the extent to which the COVID-19 pandemic will affect puberty, childhood obesity and diabetes. Nevertheless, governments, schools, and families must make all possible efforts to minimize the impact of the COVID-19 pandemic. The diabetogenic potential of SARS-CoV-2 is a matter of current research with proponents for 
and against the idea. Further studies will help delineate the pathophysiology.

Conflict of interest: No conflict of interest was declared by the authors.

\section{References}

1. Dvorsky MR, Breaux R, Becker SP. Finding ordinary magic in extraordinary times: child and adolescent resilience during the COVID-19 pandemic. Eur Child Adolesc Psychiatry 2020;1:1-3. https://doi.org/10.1007/ s00787-020-01583-8

2. Barchetta I, Cimini FA, Bertoccini L, et al. Effects of work status changes and perceived stress onglycaemiccontrol in individuals with type 1 diabetes during COVID-19 lockdown in Italy. Diabetes Res Clin Pract 2020;170:108513. https://doi.org/10.1016/j. diabres.2020.108513

3. Latronico AC, Brito VN, Carel JC. Causes, diagnosis, and treatment of central precocious puberty. Lancet Diabetes Endocrinol 2016;4:265-274. https://doi. org/10.1016/S2213-8587(15)00380-0

4. Stagi S, De Masi S, Bencini E, et al. Increased incidence of precocious and accelerated puberty in females during and after the Italian lockdown for the coronavirus 2019 (COVID-19) pandemic. Ital J Pediatr 2020;46:165.https://doi.org/10.1186/s13052-02000931-3

5. Pietrobelli A, Pecoraro L, Ferruzzi A, et al. Effects of COVID-19 lockdown on lifestyle behaviors in children with obesity living in Verona, Italy: a longitudinal study. Obesity (Silver Spring) 2020;28:1382-1385. https://doi. org/10.1002/oby.22861

6. Verzani M, Bizzarri C, Chioma L, Bottaro G, Pedicelli S, Cappa M. Impact of COVID-19 pandemic lockdown on early onset of puberty: experience of an Italian tertiary center. Ital J Pediatr 2021;47:52. https://doi. org/10.1186/s13052-021-01015-6

7. Karpati $\mathrm{AM}$, Rubin $\mathrm{CH}$, Kieszak SM, Kieszak SM, Marcus M, Troiano RP. Stature and pubertal stage assessment in American boys: the 1988-1994 third National Health and nutrition examination survey. J Adolesc Health 2002;30:205-212. https://doi. org/10.1016/s1054-139x(01)00320-2

8. Burt Solorzano CM, McCartney CR. Obesity and the pubertal transition in girls and boys. Reproduction 2010;140:399-410.https://doi.org/10.1530/REP-100119

9. Stagi S, Papacciuoli V, Boiro D, et al. Auxological and endocrinological features in internationally adopted children. Ital J Pediatr 2020;46:82. https://doi. org/10.1186/s13052-020-00832-5

10. Yang S, Guo B, Ao L, et al. Obesity and activity patterns before and during COVID-19 lockdown among youths in China. Clin Obes 2020;10:e12416. https://doi.org/ 10.1111/cob.12416.

11. Salti $R$, Tarquini $R$, Stagi $S$, et al. Age-dependent association of exposure to television screen with children's urinary melatonin excretion? Neuro Endocrinol Lett 2006;27:73-80.

12. Sangün Ö, Dündar $B$, Çömlekçi $S$, Büyükgebiz $A$. The effects of electromagnetic field on the endocrine system in children and adolescents. Pediatr Endocrinol Rev 2015;13:531-545.

13. Waldhauser F, Weiszenbacher G, Tatzer E, et al. Alterations in nocturnal serum melatonin levels in humans with growth and aging. J Clin Endocrinol Metab 1988;66:648-652. https://doi.org/10.1210/jcem66-3-648

14. Hadinia SH, Carneiro PRO, Fitzsimmons CJ, Bédécarrats GY, Zuidhof MJ. Post-photostimulation energy intake accelerated pubertal development in broiler breeder pullets. Poult Sci 2020;99:2215-2229. https://doi.org/10.1016/j.psj.2019.11.065

15. Giuseppina RU, Maddaluno I, Ricio S. Central precocious puberty and sleep patterns in COVID-19 outbreak. Paper presented at: ESPE 59th Annual Meetibg 22-26 September

16. Karatzias T, Shevlin M, Murphy J, et al. Post-traumatic stress symptoms and associated comorbidity during the COVID-19 pandemic in Ireland: a populationbased study. J Trauma Stress 2020:365-370. https:// doi.org/10.1002/jts.22565

17. Blüher M. Obesity: global epidemiology and pathogenesis. Nat Rev Endocrinol 2019;15:288-298. https://doi.org/10.1038/s41574-019-0176-8

18. Kumar S, Kaufman T. Childhood Obesity. Panminerva Med 2018;60:200-212. https://doi.org/10.23736/ S0031-0808.18.03557-7

19. Rundle AG, Park Y, Herbstman JB, Kinsey EW, Wang Y. COVID-19-related school closings and risk of weight gain among children. Obesity (Silver Spring) 2020;28:1008-1009. https://doi.org/10.1002/oby.22813

20. Pietrobelli A, Pecoraro L, Ferruzzi A, et al. Effects of COVID-19 lockdown on lifestyle behaviors in children with obesity living in verona, Italy: a longitudinal study. Obesity (Silver Spring) 2020;28:1382-1385. https://doi. org/10.1002/oby.22861

21. Storz MA. The COVID-19 pandemic: an unprecedented tragedy in the battle against childhood obesity. Clin Exp Pediatr 2020;63:477-482. https://doi.org/10.3345/ cep.2020.01081

22. Ribeiro KD da S, Garcia LRS, Dametto JF dos S, Assunção DGF, Maciel BLL. COVID-19 and nutrition: the need for initiatives to promote healthy eating and prevent obesity in childhood. Child Obes 2020;16:235237. https://doi.org/10.1089/chi.2020.0121 
23. Franckle R, Adler R, Davison K. Accelerated weight gain among children during summer versus school year and related racial/ethnic disparities: a systematic review. Prev Chronic Dis 2014;11:101. https://doi. org/10.5888/pcd11.130355

24. von Hippel, Paul T, Workman J. From kindergarten through second grade, US children's obesity prevalence grows only during summer vacations. Obesity 2016;24:2296-2300. https://doi.org/10.1002/ oby. 21613

25. Workman J. How much may COVID-19 school closures increase childhood obesity? Obesity (Silver Spring) 2020;28:1787. https://doi.org/10.1002/oby.22960

26. Brazendale K, Beets MW, Weaver RG, et al. Understanding differences between summer vs. school obesogenic behaviors of children: the structured days hypothesis. Int J Behav Nutr Phys Act 2017;14:100. https://doi.org/10.1186/s12966-017-0555-2

27. An R. Projecting the impact of the coronavirus disease-2019 pandemic on childhood obesity in the United States: a microsimulation model. J Sport Health Sci 2020;9:302-312. https://doi.org/10.1016/j. jshs.2020.05.006

28. Cuschieri S. COVID-19 panic, solidarity and equitythe Malta exemplary experience. J Public Health (Berl.): From Theory to Practice 2020;1-6. https://doi. org/10.1007/s10389-020-01308-w

29. Nagata JM, Abdel Magid HS, Pettee Gabriel K. Screen time for children and adolescents during the coronavirus disease 2019 pandemic. Obesity (Silver Spring) 2020;28:1582-1583. https://doi.org/10.1002/ oby. 22917

30. Fang K, Mu M, Liu K, He Y. Screen time and childhood overweight/obesity: a systematic review and metaanalysis. Child Care Health Dev 2019;45:744-753. https://doi.org/10.1111/cch.12701

31. Robinson TN, Banda JA, Hale L, et al. Screen media exposure and obesity in children and adolescents. Pediatrics 2017;140:97-101. https://doi.org/10.1542/ peds.2016-1758K

32. Centers for Disease Control and Prevention. National Diabetes Statistics Report, 2020. Atlanta, GA: Centers for Disease Control and Prevention, US Department of Health and Human Services. Available at: https://www. cdc.gov/diabetes/pdfs/data/statistics/NDSR_2020_ Spanish-508.pdf. Acessed 2020

33. Apicella M, Campopiano MC, Mantuano M, Mazoni L, Coppelli A, Del Prato S. COVID-19 in people with diabetes: understanding the reasons for worse outcomes. Lancet Diabetes Endocrinol 2020;8:782792. https://doi.org/10.1016/S2213-8587(20)30238-2

34. Selvin E, Juraschek SP. Diabetes epidemiology in the COVID-19 pandemic. Diabetes Care 2020;43:16901694. https://doi.org/10.2337/dc20-1295
35. Huang I, Lim MA, Pranata R. Diabtetes mellitus is associated with increased mortality and severity of disease in COVID-19 pneumonia e a systematic review, metaanalysis, and meta-regression. Diabetes Metab Syndr 2020;14:395-403. https://doi.org/10.1016/j. dsx.2020.04.018

36. Pitocco D, Tartaglione L, Viti L, et al. Lack of type 1 diabetes involvement in SARS-CoV-2 population: only a particular coincidence? Diabetes Res Clin Pract 2020;164:108220. https://doi.org/10.1016/j. diabres.2020.108220

37. Bronson SC. Letter to the editor in response to the article "Lack of type 1 diabetes involvement in the SARSCoV-2 population: only a particular coincidence?". Diabetes Res Clin Pract 2020;167:108306. https://doi. org/10.1016/j.diabres.2020.108306

38. Tatti P, Tonolo G, Zanfardino A, lafusco D. Is it fair that patients with Type 1 Diabetes (autoimmune) may be spared by the infection of COVID-19. Medical Hypothesis 2020;14:109795. https://doi.org/10.1016/j. mehy.2020.109795

39. Rabbone I, Schiaffini R, Cherubini V, Maffeis C, Scaramuzza A. Has COVID-19 delayed the diagnosis and worsened the presentation of type 1 diabetes in children? Diabetes Care 2020;43:2870-2872. https:// doi.org/10.2337/dc20-1321

40. Chee YJ, Ng SJH, Yeoh E. Diabetic ketoacidosis precipitated by COVID-19 in a patient with newly diagnosed diabetes mellitus. Diabetes Res Clin Pract 2020;164:108166. https://doi.org/10.1016/j. diabres.2020.108166

41. Li J, Wang X, Chen J, Zuo X, Zhang H, Deng A. COVID-19 infection may cause ketosis and ketoacidosis. Diabetes Obes Metab 2020;22:19351941. https://doi.org/10.1111/dom. 14057

42. Marchand L, Pecquet M, Luyton C. Type 1 diabetes onset triggered by COVID-19. Acta Diabetol 2020;57:65-66. https://doi.org/10.1007/s00592-02001570-0

43. Bonora BM, Boscari F, Avogaro A, Bruttomesso D, Fadini GP. Glycaemic control among people with type 1 diabetes during lockdown for the SARS-CoV-2 outbreak in Italy. Diabetes Ther 2020;11:1369-1379. https://doi.org/10.1007/s13300-020-00829-7

44. Di Dalmazi G, Maltoni G, Bongiorno C, et al. Comparison of the effects of lockdown due to COVID-19 on glucose patterns among children, adolescents, and adults with type 1 diabetes: CGM study. BMJ Open Diabetes Res Care 2020;8:e001664. https://doi.org/10.1136/ bmjdrc-2020-001664

45. Aragona M, Rodia C, Bertolotto A, et al. Type 1 diabetes and COVID-19: the "lockdown effect". Diabetes Res Clin Pract 2020;170:108468. https://doi.org/10.1016/j. diabres.2020.108468 
46. Iughetti L, Trevisani $\mathrm{V}$, Cattini $\mathrm{U}$, et al. COVID-19 and type 1 diabetes: concerns and challenges. Acta Biomed 2020;91:e2020033. https://doi.org/10.23750/ abm.v91i3.10366

\section{Authors contribution}

Z.A. and E.S constructed the main idea and hypothesis of the study. E.S developed the theory and organized the material and method section. E.S. evaluated the data in the results section. Discussion section of the article was written by E.S. Z.A reviewed, made necessary corrections and approved. In addition, all authors discussed the entire study and approved the final version. 